\title{
Fairy Rings and Wildlife
}

\section{JOHN G. STELFOX AND DAVID STELFOX}

\section{Abstract}

Fairy rings $25 \times 30 \mathrm{~m}$ in diam were observed on southwest-facing grasslands of the Rock Creek drainage of Montana at the 1,450 -m elevation on May 20, 1970. Within the stimulated growth portion of the rings there was 5 to 9 times as much new grass growth in proportion to old standing litter than outside the rings. Protein, calcium, and phosphorus values were 3.7, 1.6, and 3.9 times higher, respectively, for the new forage on the rings than for the old forage elsewhere. Deer use of the ring area was more than twice as great as that away from the rings, according to fecal group counts.

Fairy rings are reported to occur on rangelands in many areas of the Great Plains region, and are common in turfgrasses, pastures, and woodlands all over the world (Shantz and Piemeisel 1917; Bayless-Elliott 1926; Smith 1957; Lebeau and Hawn 1961). Some large rangeland rings are estimated to be over 200 years old. Fungi of various species have been found associated with the rings (Lebeau and Hawn 1961; Filer 1965). A commonly accepted description of the pattern of ring development involves a regular annual movement of a parasitic fungus living on grass in the soil. This movement gradually proceeds outwards, fairly uniformly in all directions from the center where it started. As it advances the fungus destroys the roots of grasses (Bayless-Elliott 1926; Filer 1965) and finally, after killing the plants consumes all the softer tissues. Deprived of food and having rendered the area unsuitable for further fungal growth by the secretion of toxic substances, the fungus frequently produces sporophores (mushrooms) and dies. The soil, meanwhile, has been greatly enriched by the saprophytic action of the fungus on dead rootlets, and by decay of old mycelium. This soil enrichment is the cause of luxuriant growth when new grass appears.

A classification system (Shantz and Piemeisel 1917) involving 3 basic types of fairy rings is as follows:

Type I, in which the grass is killed or badly damaged;

Type II, in which the grass is only stimulated;

Type III, which produces no effect upon the grass.

In southern Alberta the causal fungus is reported to be Marasmius oreades Fr. (Lebeau and Hawn 1961). In these cases a Type I ring forms similar to those reported in England (Bayless-Elliott 1926). In an eastern Colorado study, however, the only effect of $M$. oreades on grass was to stimulate growth (Shantz and Piemeisel 1917). Type I rings there were associated with Agaricus tabularis Peck.

Bayless-Elliott (1926) reported there are three zones associated with Type I fairy rings, namely: (1) an inner ring where the grass is a deeper green and more luxuriant than within the ring, and of the pasture; (2) a ring of dead or dying grass surrounding (1); (3) a narrow outer zone of stimulated grass external to (2). Toward the end of summer, zone (3) may become even broader than zone (1) in some locales (BaylessElliott 1926).

On May 20, 1970 the senior author observed fairy rings on a grassy slope of the upper Rock Creek watershed in Montana (Fig. 1). These three rings were on a southwest exposure having a slope of about $20 \%$ and at the 1,450 m elevation. The slopes showed considerable use by mule deer (Odocoileus hemionus) during winter and spring periods as well as some use by cattle. Utilization of grasses was estimated to be moderate-heavy. Vegetation consisted of approximately $75 \%$ Idaho fescue (Festuca idahoensis), 20-25\% junegrass (Koeleria cristata), and $<5 \%$ forbs.

The rings had diameters of 25 to $30 \mathrm{~m}$, of which two circles were 65 to $75 \%$ complete and the other only about 40 to $50 \%$ complete. The

Authors are research scientist, Canadian Wildlife Service, KREMU Project, P.O. Box 47146, Nairobi, Kenya, and plant pathologist, Alberta Agriculture, O.S. Longman Building, P.O. Box 8070 , Edmonton, Alberta, T6H 4P2.

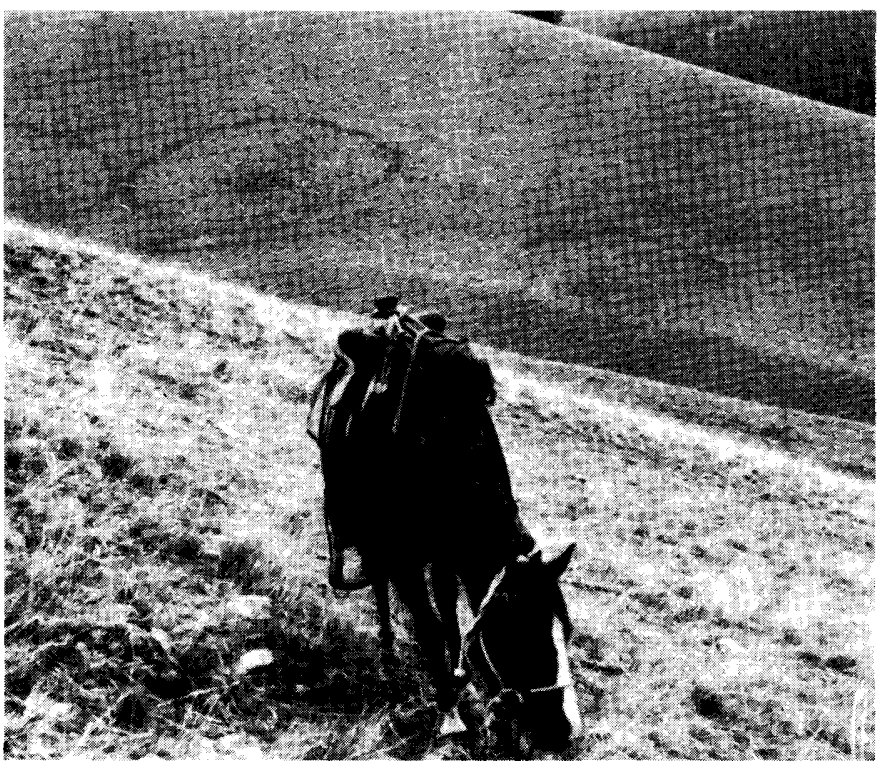

Fig. 1. Fairy rings on grasslands of Rock Creek drainage, Montana, May 20, 1970 .

open portions of the circles were on the down-slope side. Each contained a darkened center of dead vegetation (Fig. 1).

There appeared to be more deer fecal pellets on and immediately adjacent to the ring area of stimulated grass growth. On this stimulated ring most of the forage was new green growth on which the deer appeared to be feeding heavily. The forage outside the ring had little new growth but considerable mature and weathered standing litter from the previous year. The deer seemed less interested in that forage. The width of the fairy rings averaged $1.25 \mathrm{~m}$.

\section{Methods}

About $1 \mathrm{~kg}$ of grass forage was hand-plucked from the stimulated zone of the fairy ring and also from an area about $5 \mathrm{~m}$ outside the ring. These two fresh samples were then separated into new and old forage portions and weighed on a balance scale. They were then air-dried to a constant weight and re-weighed. The percent of new and old forage in each sample was calculated on both a green and an air-dried basis.

A proximate nutritive analysis (Goering and Van Soest 1970; Roach 1966; Warner and Jones 1970) was then conducted on the two mixed grass forage samples by the Alberta Agriculture Soil and Feed Testing Lab., Edmonton. Results were presented as percent protein, fiber, calcium, and phosphorus.

The number of deer fecal groups were counted and compared from two sample strips each $10 \mathrm{~m}$ long $\times 2.5 \mathrm{~m}$ wide along and adjacent to the fairy ring and at a distance of $5 \mathrm{~m}$ from the fairy ring.

\section{Results}

Within the stimulated growth portion of the fairy ring, new grass growth comprised $92.3 \%$ of the forage compared to only $17.8 \%$ outside the ring on a green-weight basis, and $78.1 \%$ and $9.0 \%$ respectively on a dried-weight basis (Table 1). There was evidently 5 to 9 times as much new growth in proportion to old standing litter on the ring than outside it.

The protein content of the new grass foliage was $18.8 \%$ compared to $5.1 \%$ for the old forage while the moisture content of the new forage was also higher (Table 2). Fiber content was twice as high on the old forage. These results suggest that the lush, nutritious grass on the fairy rings would be more palatable to deer and other grazing ungulates than would the old forage. The nutritive value of the new forage on the rings was enhanced by protein, calcium, and phosphorus values that were $3.7,1.6$ and 3.9 times higher, respectively, than those for the old forage outside the rings.

Deer use on the rings was about twice that on the grassland $5 \mathrm{~m}$ 
Table 1. Amounts of new and old grass forage within and outside fairy rings in relation to use by deer.

\begin{tabular}{lcc}
\hline & \multicolumn{2}{c}{$\%$ of Forage } \\
\cline { 2 - 3 } Type of Forage & Green Wt. & Dry Wt. \\
\hline & Within Fairy Ring \\
New grass & 92.3 & 78.1 \\
Old grass & 7.7 & 21.9 \\
Deer fecal groups $=$ & 9 within a 10 $\mathrm{m} \times 2.5 \mathrm{~m}$ strip \\
& & \\
& 5 m Outside Fairy Ring & 9.9 \\
New grass & 17.8 & 91.0 \\
Old grass & 82.2 & 4 within a $10 \mathrm{~m} \times 2.5 \mathrm{~m}$ strip \\
Deer fecal groups $=$ &
\end{tabular}

away, as revealed by a count of 9 fecal groups along the $2.5 \mathrm{~m}$ strip on and adjacent to the fairy ring compared to only 4 fecal groups on a similar sample $5 \mathrm{~m}$ outside the ring (Table 1 ).

\section{Discussion}

In the northern Great Plains region, fairy rings tend to occur on grassed soils that are dry and low in fertility (Lebeau and Hawn 1961; Shantz and Piemeisel 1917). A Type I ring is most frequently observed. On such soils the presence of rings would likely be attractive to deer, particularly during drought periods and in early spring. Results of pellet counts in zones (1) and (3) on the rings appearing in Figure 1 would indicate that this attraction occurs. Studies by BaylessElliott (1926) and Shantz and Piemeisel (1917) indicate that physical and chemical changes in the soil result from outward movement of the fairy ring fungus. The middle zone (2) soil always contains less moisture than do the zones on either side. This is due to the dense mat of fungal mycelium preventing percolation of rainwater through to plant roots. The soil of this zone, however, gradually becomes greatly enriched through the decomposition of plant rootlets and fungal hyphae. During this period there is a reduction in soil organic matter
Table 2. Nutritional levels of new grass forage within and outside fairy rings on May 20, 1970.

\begin{tabular}{lccccc}
\hline \hline Type of Forage & $\begin{array}{c}\text { Moisture } \\
\%\end{array}$ & $\begin{array}{c}\text { Protein } \\
\%\end{array}$ & $\begin{array}{c}\text { Fiber } \\
\%\end{array}$ & $\begin{array}{c}\text { Phosphorus } \\
\%\end{array}$ & $\begin{array}{c}\text { Calcium } \\
\%\end{array}$ \\
\cline { 2 - 6 } $\begin{array}{l}\text { New growth within } \\
\text { fairy ring }\end{array}$ & 7.4 & 18.8 & 23.4 & .35 & .37 \\
$\begin{array}{l}\text { Mature, weathered } \\
\text { growth, outside ring }\end{array}$ & 6.9 & 5.1 & 47.3 & .23 & .09 \\
\hline
\end{tabular}

and this, in turn, furnishes and quantity of readily available nitrogen for subsequent green plant growth (Table 2). The dead zone and inner stimulated zone soils gain in total nitrogen while the outer stimulated soil zone has less nitrogen than in the pasture generally. The latter may be due to the face that the grasses in the outer stimulated zone are taking up more soil nitrogen than in the normal pasture.

\section{Literature Cited}

Bayless-Elliott, J.S. 1926. Concerning fairy rings in pastures. Ann. App. Biol. 13: $277-288$.

Filer, T.H. 1965. Damage to turfgrasses caused by cyanogenic compounds produced by Marasmius oreades, a fairy ring fungus. Plant Dis. Rep. 49: 571-574.

Goering, H.K., and P.J. Van Soest. 1970. Forage fibre analyses. Agr. Handbk. No. 379. Agr. Res. Serv., U.S. Dep. Agr.

Lebeau, J.B., and E.J. Hawn. 1961. Fairy rings in Alberta. Can. Plant Dis. Surv. 4: 317-320.

Roach, A.G. 1966. Application of technicon auto analyzer equipment to the routine determination of calcium and phosphorus in animal feedstuffs. 5th Int. Sympos. on Automation in Analytical Chemistry. 1965.

Shantz, H.L., and R.L. Piemeisel. 1917. Fungus fairy rings in eastern Colorado and their effect on vegetation. J. Agr. Res. 11: 191-246. Smith, J.D. 1957. Fairy rings. J. Sports Turf Inst. 9: 1-29.

Warner, M.H., and J.B. Jones Jr. 1970. A rapid method for nitrogen determination in plant tissue. Soil Sci. and Plant Analysis. 1: 109-114.

\section{Position Announcement}

POSITION:

Fulltime faculty member, Department of Botany and Range Science. Brigham Young University

\section{CLOSINGDATE: $\quad$ March1,1979}

Range Management faculty position in a Botany and Range Science Department with 18 faculty members. The well-balanced Range program is a little more than a decade old. The person who fills the vacant position will be expected to teach in the Range Science program, but will on occasion also assist in teaching other non-range courses in the department. Examples of non-range courses which may be taught are general biology, ecology and conservation. In addition to teaching duties, the individual will be expected to carry out an active research program. Teaching load depends to an extent, upon the nature and quality of research.
QUALIFICATIONS: Minimum of Ph.D. degree in Range Science or Range Management. Post Ph.D. experience is preferred.

SALARY AND RANK: Commensurate with experience.

CONTRACT:

$$
\begin{aligned}
& \text { W.M. Hess, Chairman Search } \\
& \text { Committee } \\
& \text { Department of Botany and Range } \\
& \text { Science } \\
& 245 \text { WIDB, Brigham Young Uni- } \\
& \text { versity } \\
& \text { Provo, Utah } 84602
\end{aligned}
$$

(801) $374-1211$ Ext. 2451

Brigham Young University hires qualified handicapped persons and does not discriminate on the basis of race, color, national origin, sex, or age. 